\title{
Vacuum induction melting and vacuum arc remelting of Co-Al-W-X gamma-prime superalloys
}

\author{
Erin T. McDevitt ${ }^{\mathrm{a}}$ \\ ATI Specialty Materials, 2020 Ashcraft Ave. PO Box 5030 Monroe, NC 28110 US
}

\begin{abstract}
Co-Al-W alloys strengthened with the $\mathrm{L}_{2}$ gamma-prime phase have promise as next generation high temperature materials due to the ability to engineer a high gamma-prime content alloy with a higher gammaprime solvus and higher melting point than many Ni-base gamma-prime strengthened alloys. Furthermore, these Co-Al-W gamma-prime alloys are interesting as potential cast-and-wrought alloys because they have a relatively narrow range of solidification temperature and large range of temperature between the gamma-prime solvus and the solidus, suggesting than manufacturing via an ingot metallurgy route would be feasible. However, since J. Sato et al discovered gamma-prime in the Co-Al-W alloy system in 2006, the focus in the literature has been on characterizing the structure and properties of these alloys and measuring and assessing the thermodynamics of the alloy system primarily for application as castings for turbine blade applications. To date the author is not aware of any publications describing the microstructure of vacuum induction melted, vacuum arc remelted ingots of a size more than about $2 \mathrm{~kg}$. Most work has been performed using small, laboratory-scale, cast-and-hot-rolled samples or samples cast as single crystals. This paper presents ATI's experience in assessing the feasibility of manufacturing a cast-and-wrought billet product in the Co-Al-W-X alloy system. Three $22 \mathrm{~kg}$ heats were produced to examine a small range of alloy compositions of potential commercial interest: Co-9Al-9W, Co-9Al-10W-2Ti, and Co-9Al10W-2Ti-0.02B, respectively. Each heat was vacuum-induction-melted and vacuum-arc-remelted then open-die forged. The ingot microstructure has been characterized. Hot workability during billetizing will be described and microstructure and hardness of hot worked and heat treated product will be presented.
\end{abstract}

\section{Introduction}

As the operating temperature of gas turbine engines continues to rise in an effort to increase engine efficiency, designers are forced to use more Ni-base superalloys strengthened by higher volume fractions of the $\mathrm{L}_{2}$ gamma-prime phase, for example alloy 720 , for turbine disk applications with service temperatures up to about $760{ }^{\circ} \mathrm{C}$. Such disk alloys are often produced using ingot metallurgy, but not without challenges. These higher gamma-prime content superalloys are generally more highly alloyed and thus have a large solidification temperature range; thereby, they are prone to segregation during vacuum arc remelting or electroslag remelting. The segregation and the associated defects, e.g. freckles or white spots, limits the practical diameter to which these alloys can be produced to those where fast enough solidification behavior can be achieved to limit segregation. Those Ni-base disk alloys with gamma-prime content exceeding $40 \%$ also generally have a narrow temperature range in which to forge between the gammaprime solvus and the solidus temperature. The kinetics of gamma-prime formation is typically quite fast, so that gamma-prime precipitation during billetizing can make these alloys subject to cracking during hot working.

\footnotetext{
${ }^{a}$ Corresponding author: erin.mcdevitt@atimetals.com
}

In 2006, J. Sato et al. discovered the $\mathrm{L}_{2}$ gamma-prime phase in the Co-Al-W alloy system [1]. This alloy system has the potential for use in high temperature gas turbine applications because such alloys can have high gammaprime contents (up to 90 vol.\%) with a high gammaprime solvus temperature [2] and correspondingly higher temperature capability than many Ni-base superalloys. Co-Al-W-X alloys have been produced that have high temperature strength comparable to Waspaloy [1], better creep resistance than many Ni-base disk or blade alloys [3], and a high gamma prime solvus [2,4] temperature. Such performance is suitable for turbine disk or casing applications.

Furthermore, many of the thermal-physical properties of these alloys are such that manufacturing via ingot metallurgy appears feasible. Co-Al-W-X alloys have a narrow solidification temperature range [2,4], a large difference between the solidus and the gamma-prime solvus $[2,4]$, and a relatively low flow stress at hot working temperatures [5]. A narrow solidification temperature range is beneficial in alloys produced by ingot metallurgy due to a lower propensity for segregation than an alloy with a large solidification temperature range. That lower likelihood for segregation in turn could allow casting of larger diameter ingots of gamma-prime Co-Al-W alloys than Ni-base alloys with similar gamma-prime contents. Today, Ni-base disk alloys with high temperature 
capability are moving to powder manufacturing because segregation makes it difficult for ingot metallurgy to produce an ingot and billet of large enough diameter to serve as feedstock for disk forgings for new, high thrust engines. The combination of relatively low flow stress and a large difference between the solidus and the gammaprime solvus should provide a wide temperature range for billetizing. Billetizing above the gamma-prime solvus could reduce the propensity for cracking compared to $\mathrm{Ni}$ base alloys that are often forged near or sub-solvus.

Much of the research to date has been focused on phase equilibria and the effect of quaternary or quinary alloy additions to the base ternary system. This paper shows the results of work done to explore the feasibility of manufacturing cast-and-wrought gamma-prime Co-Al-W alloys at a commercially important scale for applications in land-based and aerospace turbine engines.

\section{Experimental procedure}

\subsection{Melting and casting}

Three nominal compositions were chosen for this preliminary investigation. The first was a base, ternary Co-9Al-9W alloy; the second was a Co-9Al-9W-2Ti quaternary alloy where $\mathrm{Ti}$ was added to significantly increase the gamma-prime content and the gamma-prime solvus [2]; and the third composition was a Co-9Al-9W2Ti-0.02B alloy heat where B was added to increase ductility [5]. Each heat weighed nominally $22 \mathrm{~kg}$ and was made using commercially pure, virgin, raw materials. They were vacuum induction melted (VIM) and cast as $76 \mathrm{~mm}$ diameter electrodes into carbon steel molds. Each electrode was then vacuum arc remelted (VAR) to produce $102 \mathrm{~mm}$ diameter ingots.

\subsection{Homogenization}

A laboratory study was conducted to identify an acceptable homogenization practice. Heat treatment specimens were excised from near the top of the Co-9Al-9W and Co-9Al$9 \mathrm{~W}-2 \mathrm{Ti}$ ingots and annealed at $1204^{\circ} \mathrm{C}$ for 12 to $48 \mathrm{~h}$. The ingots were homogenized at $1204^{\circ} \mathrm{C}$ for $48 \mathrm{~h}$ and air cooled.

\subsection{Hot working and heat treatment}

Transverse tensile specimens were cut from the top of all three as-homogenized ingots and high strain rate $(10 \mathrm{~mm} / \mathrm{s})$ tensile tests (ASTM E21-09) were performed at temperatures in the range between $1010^{\circ} \mathrm{C}$ and $1149^{\circ} \mathrm{C}$ to measure the ductility of the as-homogenized structure at hot working temperatures. Additionally, heat treatment specimens were cut from the ingots and annealed at $1010^{\circ} \mathrm{C}$ for times up to $1 \mathrm{~h}$ to investigate the precipitation of gamma-prime or other second phases that may form during hot working.

Forging was carried out above the gamma-prime solvus for all of the ingots. The Co-9Al-9W ingot was straight drawn on an open die press at $1149^{\circ} \mathrm{C}$. The Co-9Al-9W$2 \mathrm{Ti}$ ingot was upset forged to $80 \%$ of its initial height at $1079{ }^{\circ} \mathrm{C}$.
The Co-9Al-9W-2Ti-0.02B ingot was cut into eight pieces then forged in order to investigate the effect of the amount of reduction on the recrystallization behavior during hot working. One piece was upset forged to $80 \%$ of its initial height in one step at $1149^{\circ} \mathrm{C}$. A second piece was upset forged to $70 \%$ of its initial height in one step at $1149{ }^{\circ} \mathrm{C}$. A third piece was upset forged to $60 \%$ of its initial height in two steps at $1149^{\circ} \mathrm{C}$. Three pieces were upset forged to $60 \%$ of their initial height in two steps at $1149{ }^{\circ} \mathrm{C}$ then placed on their side and forged to a final thickness of 12 to $25 \mathrm{~mm}$.

Those pieces that were forged to 12 and $18 \mathrm{~mm}$ in thickness were solution annealed at $1149^{\circ} \mathrm{C}$ for $2 \mathrm{~h}$ then age hardened at $899^{\circ} \mathrm{C}$ for $24,48,72,96$, and $240 \mathrm{~h}$, respectively.

After hot working, samples from both ingots were heat treated at $1038^{\circ} \mathrm{C}$ to $1121^{\circ} \mathrm{C}$ for $30 \mathrm{~min}$ to $8 \mathrm{~h}$ to further investigate precipitation and/or dissolution of second phase precipitates.

\subsection{Microscopy}

Metallography specimens were excised from material at all stages of the conversion experiments. These specimens, along with any heat treatment specimens, were prepared for metallography using standard techniques. Polished specimens were etched using Kallings reagent or an $\mathrm{HCl}$ $+\mathrm{H}_{2} \mathrm{O}_{2}$ etchant, and characterized using a combination of optical microscopy, scanning electron microscopy (SEM), and energy dispersive spectroscopy (EDS). Hardness was measured on age hardened specimens.

\section{Results}

\subsection{Melting, casting, and homogenization}

VIM melting the raw material was successful using melt practices typical of Ni-base and Co-base superalloys, despite the high refractory element content of these alloys. Induction current and total melting time were consistent with Ni-base alloy practices. There was no evidence of undissolved $\mathrm{W}$ raw material in the ingot. The final alloy compositions were very close to the aim compositions for each heat (Table 1). All composition measurements were made on samples from as-homogenized ingots. The ingot microstructure of all the heats was typical of alloys produced using VAR. The ingot microstructure of the Co-9Al-9W heat did not exhibit a significant amount of interdendritic eutectic phase, rather only shrinkage porosity was observed in the interdendritic regions (Fig. 1), consistent with published results for small castings [4]. The two Ti containing heats did show the presence of eutectic solidification (Fig. 1), but no evidence of intermetallic second phases.

Some elemental partitioning during solidification was observed (Fig. 2). Ti strongly partitioned to the liquid during solidification resulting in Ti-rich interdendritic regions in the ingot. W partitioned to the solid during solidification leaving the interdendritic regions depleted in $\mathrm{W}$. The interdendritic liquid was also enriched in $\mathrm{Al}$; however $\mathrm{Al}$ was also strongly present in the solid. Co was nearly uniformly present throughout the ingot microstructure. 
Table 1. Aim and measured composition for the three experimental heats.

\begin{tabular}{|l|l|l|l|l|l|l|}
\hline Heat & \multicolumn{2}{|l|}{ Co-9Al-9W } & \multicolumn{2}{l|}{ Co-9Al-9W-2Ti } & \multicolumn{2}{l|}{ Co-9Al-9W-2Ti-0.02B } \\
\hline Element & $\begin{array}{l}\text { Measured } \\
{[w t . \%]}\end{array}$ & $\begin{array}{l}\text { Aim } \\
{[w t . \%]}\end{array}$ & $\begin{array}{l}\text { Measured } \\
{[w t . \%]}\end{array}$ & Aim [wt.\%] & $\begin{array}{l}\text { Measured } \\
{[w t . \%]}\end{array}$ & Aim [wt.\%] \\
\hline Co & 71.7 & 71.8 & 69.7 & 70.8 & 70.1 & 70.8 \\
\hline $\mathrm{Al}$ & 3.5 & 3.6 & 3.5 & 3.6 & 3.6 & 3.6 \\
\hline $\mathrm{W}$ & 24.4 & 24.6 & 25.2 & 24.2 & 24.7 & 24.2 \\
\hline $\mathrm{Ti}$ & 0.0 & 0 & 1.3 & 1.4 & 1.3 & 1.4 \\
\hline Other & 0.4 & 0 & 0.3 & 0 & 0.3 & trace \\
\hline
\end{tabular}
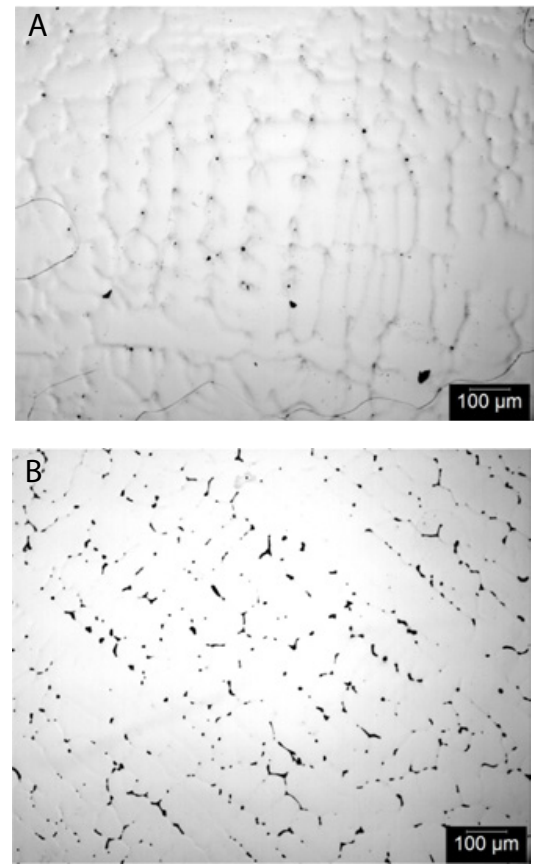

Figure 1. As-VAR cast microstructure of the Co-9Al-9W ingot (A) and the Co-9Al-9W-2Ti ingot (B).

The lab homogenization study showed elimination of the dendritic structure and good homogenization in both the heat without $\mathrm{Ti}$ and the Ti-containing heats after $24 \mathrm{~h}$ at $1204{ }^{\circ} \mathrm{C}$ (Fig. 3). The ingots were homogenized for $48 \mathrm{~h}$ prior to hot working in order to account for ingot heating time and to insure complete homogenization of the Ti-rich regions of the microstructure.

The mechanical properties of the as-VAR-andhomogenized ingot are one measure of the hot workability of the ingot at the start of billetization. The ductility of the ingot as a function of temperature measured in high strain rate tensile tests usually provides good insight regarding how an ingot should be hot worked. Therefore, high strain rate tensile tests were conducted at temperatures of interest for hot working using test bars extracted from the as-homogenized ingots. The Co-9Al-9W ingot had essentially no ductility at temperatures between $1010^{\circ} \mathrm{C}$ and $1121^{\circ} \mathrm{C}$ (Fig. 4). In contrast, the Co-9Al-9W-2Ti ingot exhibited relatively good ductility for an as-homogenized ingot at $1066^{\circ} \mathrm{C}$ to $1093{ }^{\circ} \mathrm{C}$. There was no ductility in that ingot at $1121^{\circ} \mathrm{C}$. The $\mathrm{B}$ containing ingot was tested at $1093{ }^{\circ} \mathrm{C}$ and $1121^{\circ} \mathrm{C}$ and had reduction in area of $32 \%$ and $57 \%$, respectively, indicating acceptable ductility for hot

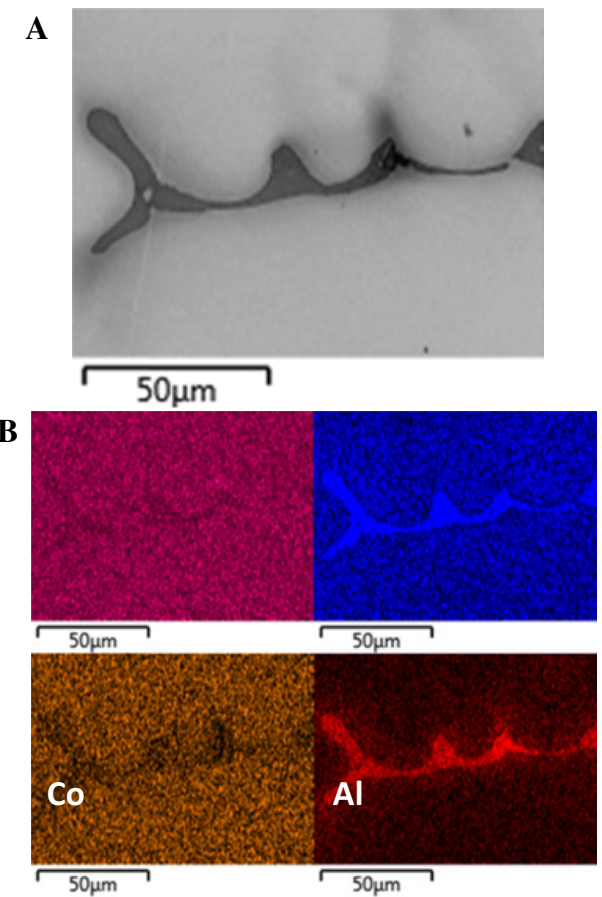

Figure 2. Back-scattered electron image (A) of an interdendritic region of the as-cast Co-9Al-9W-2Ti ingot and corresponding EDS maps (B) for $\mathrm{Co}, \mathrm{Al}, \mathrm{W}$, and Ti.

working. The gauge sections of the tensile specimens were cross-sectioned and examined using optical microscopy and SEM. The tensile specimens from the Co-9Al$9 \mathrm{~W}-2 \mathrm{Ti}$ ingot showed that $\mathrm{Co}_{3} \mathrm{~W}$ intermetallic particles precipitated on the as-homogenized grain boundaries while undergoing strain in the tensile test (Fig. 5). Test specimens from the Co-9Al-9W heat did not show any precipitation of intermetallic particles at any of the test temperatures. Those specimens experienced intergranular failure with no ductility.

Limited recrystallization accompanied the $\mathrm{Co}_{3} \mathrm{~W}$ precipitation in the gauge section of test specimens from the two Ti containing heats undergoing significant reduction in area; while no recrystallization was observed in the specimens from the Co-9Al-9W specimen at any test temperature (Fig. 5). However, it is interesting to note that heat treating metallographic specimens cut from the ashomogenized ingots for up to $60 \mathrm{~min}$ at $1024{ }^{\circ} \mathrm{C}$ did not result in the precipitation of any second phases in the Ticontaining or non-Ti-containing heats. The $\mathrm{Co}_{3} \mathrm{~W}$ particles 

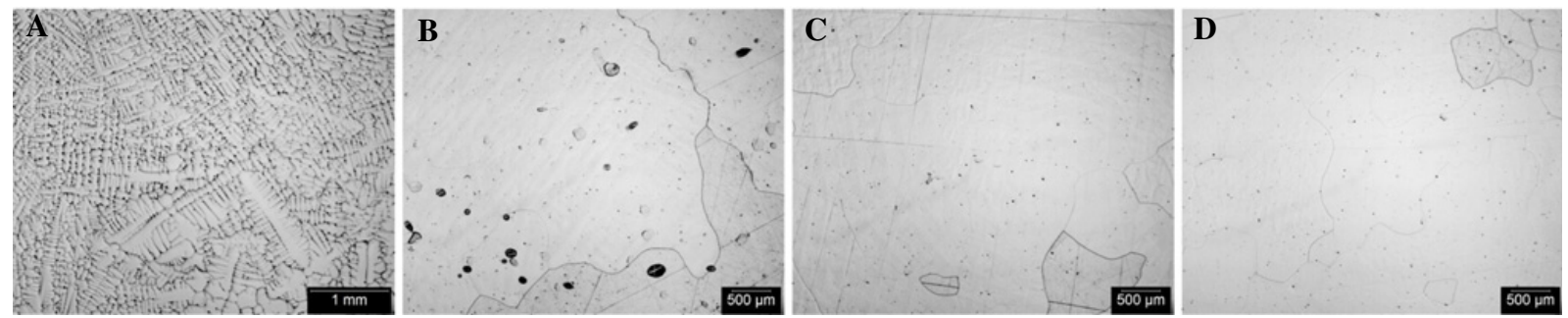

Figure 3. The microstructure of the Co-9Al-9W-2Ti ingot (A) as-VAR, and after homogenization at $1024{ }^{\circ} \mathrm{C}$ for (B) $12 \mathrm{~h},(\mathrm{C}) 24 \mathrm{~h}$, and (D) $48 \mathrm{~h}$.

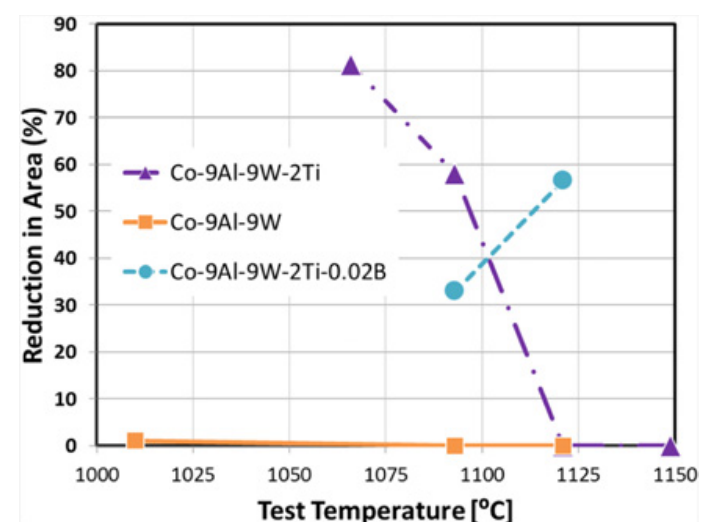

Figure 4. Reduction in area as a function of test temperature for high strain rate tensile tests of each heat

only were observed in combination with hot working strain.

\subsection{Hot working Co-9Al-9W and Co-9Al-9W-2Ti}

The Co-9Al-9W heat was open die forged by straight drawing the ingot from $1149^{\circ} \mathrm{C}$. Little reduction in cross section was achieved before severe end cracking of the ingot occurred. Hot working was stopped and the ingot was allowed to air cool.

Sectioning the ingot after hot working showed that the ingot cracked severely through the center and none of the ingot was sound (Fig. 6). However, while the billet cracked during hot working, none of the cracks ran catastrophically. Rather, the surface stayed intact and suffered only minor shallow cracks. This behavior was a reason for optimism as it is in contrast to the behavior observed in many high gamma-prime content Ni-base superalloys where severe, brittle cracking can take place if the proper hot working temperature is not maintained.

The Co-9Al-9W-2Ti ingot was upset forged $20 \%$ of its initial height at $1079^{\circ} \mathrm{C}$. A small surface crack was observed at the completion of the upset. That crack opened while trying to draw the ingot back to a bar and hot working was stopped.

After hot working, metallography specimens were cut from both ingots. $\mathrm{Co}_{3} \mathrm{~W}$ intermetallic particles were observed on grain boundaries in the Co-9Al-9W-2Ti forging. No second phase particles were observed in the Co-9Al-9W forging.

Additional specimens, cut from the as-hot worked pieces, were heat treated between $1038^{\circ} \mathrm{C}$ and $1121^{\circ} \mathrm{C}$

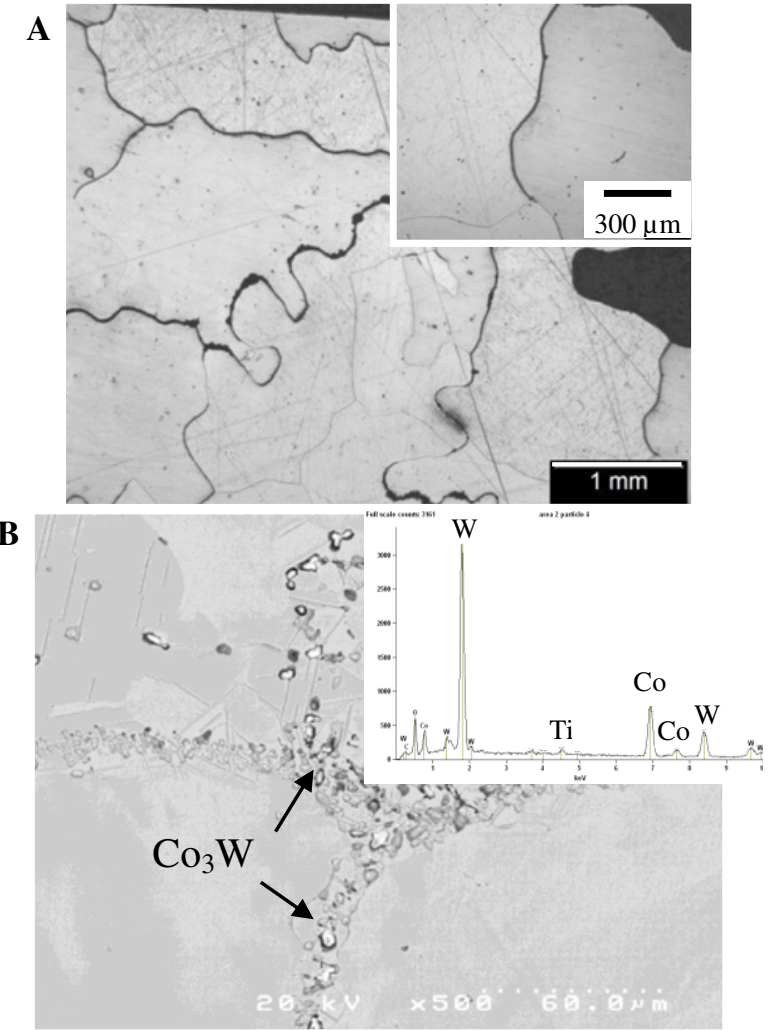

Figure 5. Cross-sectional micrographs from the gauge section of high strain rate tensile tests. (A) Optical micrograph from Co-9Al-9W tested at $1093^{\circ} \mathrm{C}$. (Inset) higher magnification. (B) Back-scattered electron image from Co-9Al-9W-2Ti tested at $1093^{\circ} \mathrm{C}$ and representative EDS spectra from grain boundary precipitates.

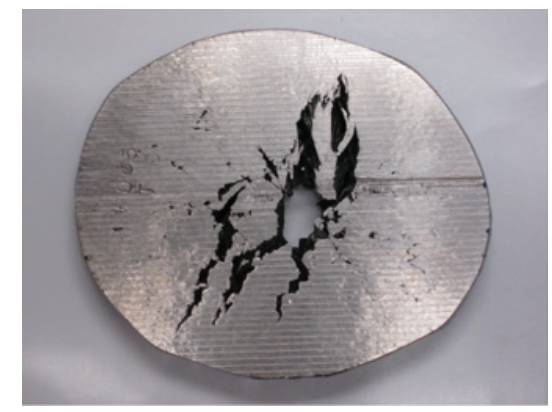

Figure 6. Cross sectional photograph of the Co-9Al-9W ingot after hot working. 

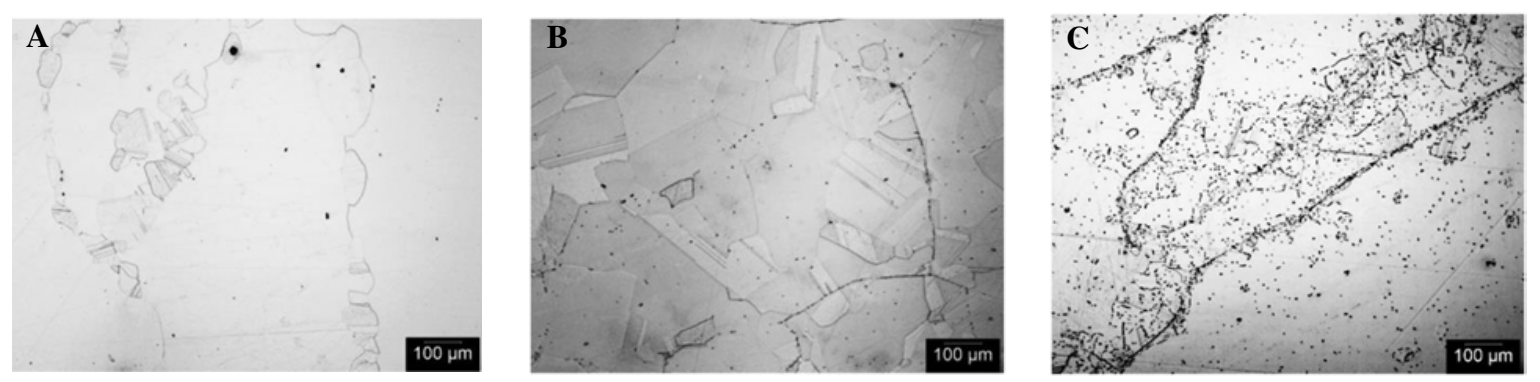

Figure 7. Optical micrographs of hot worked and annealed material. (A) Co-9Al-9W, $1 \mathrm{~h}$ at $1066^{\circ} \mathrm{C}$. (B) Co-9Al-9W-2Ti, $8 \mathrm{~h}$ at $1066^{\circ} \mathrm{C}$. (C) Co-9Al-9W-2Ti, $8 \mathrm{~h}$ at $1121^{\circ} \mathrm{C}$.

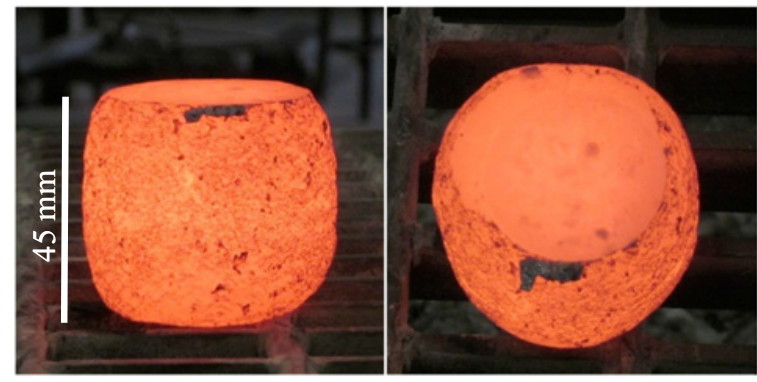

Figure 8. An as-forged piece from the Co-9Al-9W-0.02B ingot. This piece was reduced to $60 \%$ of its initial height in two steps at $1149^{\circ} \mathrm{C}$.

for up to $8 \mathrm{~h}$. In the Co-9Al-9W material, there was no significant dynamic recrystallization that occurred during hot working. However, limited static recrystallization was observed in heat treatment specimens after annealing the specimens for $1 \mathrm{~h}$ to $2 \mathrm{~h}$. The Co-9Al-9W-2Ti ingot showed evidence of minor amounts of dynamic recrystallization during hot working in addition to the grain boundary decoration by $\mathrm{Co}_{3} \mathrm{~W}$ particles. Heat treating at $1038^{\circ} \mathrm{C}$ to $1093{ }^{\circ} \mathrm{C}$ produced both intergranular and intragranular precipitation of $\mathrm{Co}_{3} \mathrm{~W}$ particles (Fig. 7).

At $1121^{\circ} \mathrm{C}$, the $\mathrm{Co}_{3} \mathrm{~W}$ particles that had precipitated during hot working dissolved with increasing annealing time.

\subsection{Hot working Co-9AI-9W-2Ti-0.02B}

The pieces cut from the Co-9Al-9W-0.02B homogenized ingot were forged using what was learned from forging the other two ingots. Every piece was successfully upset from $20 \%$ to $40 \%$ of initial height without any cracks forming (for example, Fig. 8).

During hot working, $\mathrm{Co}_{3} \mathrm{~W}$ precipitated throughout the microstructure. A greater amount of precipitation was observed in the pieces upset $40 \%$ compared to those upset only $20 \%$.

The pieces upset $40 \%$ (effective total strain of 1.6) were subsequently forged further by turning a piece on its side and either drawing it back to a bar or forging it into a flat plate. Both practices were successful in creating acceptable wrought microstructures with significant grain refinement and the absence of the cast microstructure. Some surface cracking was observed on all the forgings. For the samples drawn back into bars, cracking occurred at the corners when the pieces became too cold for forging.
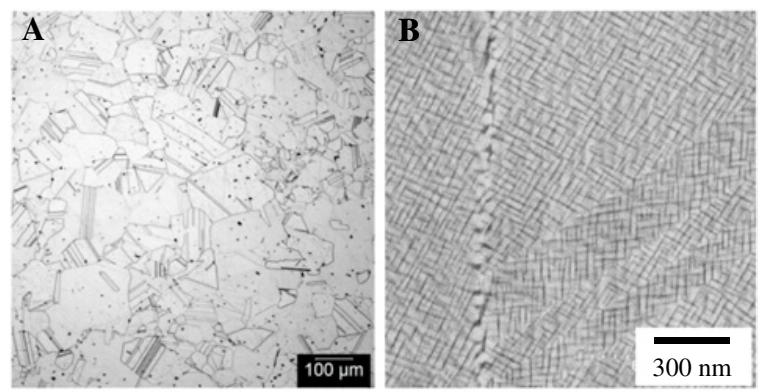

Figure 9. Optical micrographs from a piece from the Co-9Al$9 \mathrm{~W}-0.02 \mathrm{~B}$ ingot. This piece was reduced to $60 \%$ of its initial height in two steps at $1149^{\circ} \mathrm{C}$. (A) Solution annealed at $1149^{\circ} \mathrm{C}$ for 2 hours. (B) Backscattered scanning electron image of a sample solution-annealed-and-aged at $899^{\circ} \mathrm{C}$ for 240 hours.

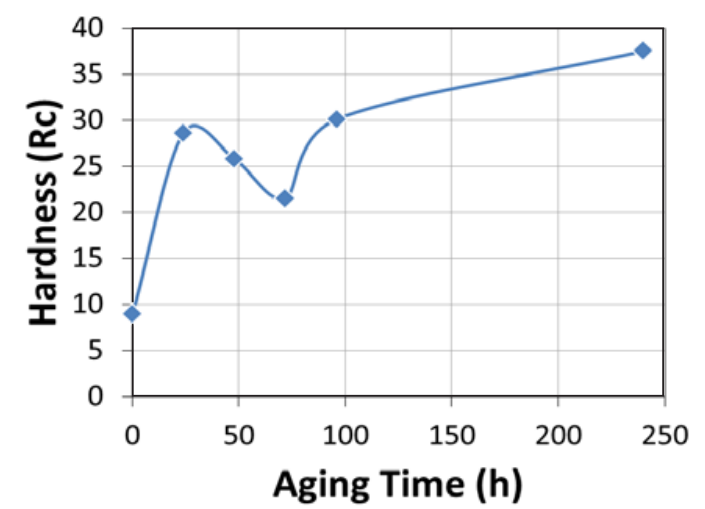

Figure 10. Rockwell $\mathrm{C}$ hardness of the Co-9Al-9W-0.02B alloy as a function aging time at $899^{\circ} \mathrm{C}$.

After solution annealing at $1149^{\circ} \mathrm{C}$ for 2 hours, the microstructure of the forgings was fully recrystallized with a grain size of ASTM 3-4 (Fig. 9). After aging the samples for up to 240 hours, the gamma-prime phase precipitated as roughly cuboidal precipitates about $300 \mathrm{~nm}$ in size. The volume fraction of gamma-prime phase was greater than $80 \%$ (Fig. 9).

The hardness was measured as a function of aging time (Fig. 10). The hardness of the sample aged for 240 hours was about the same as the typical hardness of Waspaloy in the fully age hardened condition. 


\section{Discussion}

The melting and solidification behavior observed for all three compositions was typical of VAR produced superalloys. The low degree of segregation upon solidification and the absence of TCP phases in the as-cast structure support the notion that these alloys are suitable for production of ingots of a commercially important diameter.

The low ductility of the as-homogenized Co-9Al$9 \mathrm{~W}$ ingot at all high strain rate test temperatures is an indication that billetizing this composition may not be possible. A minimum level of grain boundary strength is required for hot working. Others have reported good hot workability of small laboratory samples in this alloy system [1]. One possibility for the contradictory observation is that the fast solidification rates for those much smaller castings resulted in higher ductility due to smaller as-cast grain size. Another possible explanation for the difference in hot workability could be the choice of raw materials used to produce the alloys. In this study, commercially pure feedstock was used for VIM melting resulting in $0.4 \mathrm{wt} . \%$ of unspecified elements $(\mathrm{C}, \mathrm{Fe}, \mathrm{P}$, $\mathrm{S}$, others) in the final ingot. It is possible that trace amounts of a deleterious element significantly reduced grain boundary strength and is responsible for low ashomogenized ductility in the Co-9Al-9W alloy.

In contrast, the Ti containing composition variants had relatively good ductility for an as-homogenized ingot in high strain rate tensile tests. It is clear that the better ductility is the result of the precipitation of $\mathrm{Co}_{3} \mathrm{~W}$ particles along grain boundaries in the presence of an applied strain. However, the mechanism for improved ductility due to the precipitation of these particles is not clear at this time.

It is also interesting that the $\mathrm{Co}_{3} \mathrm{~W}$ particles did not precipitate with heat treatment alone at the forging temperatures, but rather required some applied strain to for grain boundary precipitation to occur. The presence of $\mathrm{Co}_{3} \mathrm{~W}$ particles during hot working is fortuitous and beneficial in hot working these alloys. The presence of $\mathrm{Co}_{3} \mathrm{~W}$ should permit hot working at temperatures above the gamma-prime solvus without the risk of excessive grain growth. One can expect that these alloys lend themselves to production of fine grain billet with the risk for grain growth being not during hot working, but rather during solution annealing as it is a requirement that the $\mathrm{Co}_{3} \mathrm{~W}$ be put back into solution in order to maximize the amount of gamma-prime in the fully heat treated alloy.

\section{Conclusion}

It has been demonstrated that an ingot metallurgy route for producing cast-and-wrought $\mathrm{Co}-\mathrm{Al}-\mathrm{W}-\mathrm{X}$ gamma-prime alloys is feasible and that there are some inherent traits in the alloys that might facilitate ease of manufacturing. VIM/VAR ingot production is viable for scale up to commercial production and the promise for large diameter ingots with acceptable segregation remains. In the ternary, Co-9Al-9W system, significant hurdles remain to converting the ingot to billet due to the low ductility of the as-cast structure. In the Ti-containing quaternary alloys investigated, successful conversion to billet has been demonstrated in the lab and is feasible for sizes of commercial significance. The hot workability of the $\mathrm{Ti}$ containing alloys was better due to an increase in ingot ductility by the precipitation of $\mathrm{Co}_{3} \mathrm{~W}$ particles when the ingot is subjected to a strain. Future work includes developing billet conversion processing capable of producing a fine grain billet suitable for disk forging or further processing to rolled bar, shapes, or sheet products.

Ultimately, alloy compositions that have static and dynamic properties of interest for gas turbine OEM's will need to be developed and the billet conversion practices devised for these model alloy systems will require adaptation to those alloys of commercial interest.

\section{References}

[1] J. Sato, T. Omori, I. Ohnuma, R. Kainuma, and K. Ishida, Science 312, 90-91 (2006)

[2] A. Bauer, S. Neumeier, F. Pyczak, M. Goken, Scripta Mat. 63, 1197-1200 (2010)

[3] M. Titus, A. Suzuki, T. Pollock, in: E. Huron et al. (Eds.), Superalloys 2012: 12th International Symposium on Superalloys 823-832 (2012)

[4] T. Pollock, J. Bibbern, M. Tsunekane, J. Zhu, and A. Suzuki, JOM 62, 58-63 (2010)

[5] K. Sinagawa, T. Omori, K. Oikawa, R. Kainuma, K. Ishida, Scripta Mat. 61, 612-615 (2009) 